Based on the purpose and research tasks, 6 groups of future teachers were created. The first group includes subjects with a low level of anxiety (LA) - 10 people, the second one with a high level of anxiety (HA) - 10 people, the third group - with a low level of aggression - 10 people (LA), the fourth - with a high level of aggression (HA) - 10 people, the fifth group - subjects with a high level of conflict resistance (HC), the sixth - with a low (LC). By means of the qualitative analysis the information on individual-typical features of intelligence of persons with various levels of the specified properties was received, their comparison was carried out. Future teachers with high anxiety, high aggression, low conflict resistance are inferior to colleagues with opposite characteristics in a number of parameters of general and social intelligence. As shown by the results of observations and conversations with these subjects, this leads to significant problems in their professional development, creates for them certain difficulties in various spheres of life. Qualitative analysis has shown that anxiety, aggression and conflict resilience can act as inhibitors of intelligence. However, firstly, it depends on their severity (high anxiety, high aggression and low conflict resistance can act as inhibitors) and secondly, if anxiety acts as an inhibitor, both at the cognitive-stylistic and content-personal levels of intelligence, aggression and conflict resistance act only on the latter one. In addition, their influence affects social intelligence and, unlike anxiety, does not extend to general intelligence. teachers.

Keywords: intelligence, general intelligence, social intelligence, cognitive styles, intelligence inhibitors, future

Подано до редакиії 10.02.2021

УДК 378.018.43:004]:61-057.875:578.834

DOI: https://doi.org/10.24195/2414-4665-2021-1-3

Mariia Bondarenko,

PhD (Candidate of Biological Sciences), assistant, Department of Anatomy and Pathological Physiology,

ESC "Institute of Biology and Medicine" of Taras Shevchenko National University of Kyiv,

2, Akademika Hlushkova Avenue, Kyiv, Ukraine,

Valentyna Kurovska,

PhD (Candidate of Medical Sciences), assistant, Department of Fundamental Medicine,

ESC “Institute of Biology and Medicine” of Taras Shevchenko National University of Kyiv,

2, Akademika Hlushkova Avenue, Kyiv, Ukraine,

Artem Okhrei,

PhD (Candidate of Biological Sciences), assistant, Department of Anatomy and Pathological Physiology,

ESC "Institute of Biology and Medicine" of Taras Shevchenko National University of Kyiv,

2, Akademika Hlushkova Avenue, Kyiv, Ukraine,

Olga Podpalova,

assistant of Department of Fundamental Medicine, ESC "Institute of Biology and Medicine" of Taras Shevchenko National University of Kyiv,

2, Akademika Hlushkova Avenue, Kyiv, Ukraine,

Yevdokiia Reshetnik,

PhD (Candidate of Biological Sciences), assistant,

Department of Anatomy and Pathological Physiology

ESC "Institute of Biology and Medicine" of Taras Shevchenko National University of Kyiv,

2, Akademika Hlushkova Avenue, Kyiv, Ukraine

\title{
PROBLEMS OF DISTANT LEARNING OF MEDICAL STUDENTS DURING THE COVID-19 PANDEMIC
}

Traditionally, education in medical universities has huge practical part. However, during the COVID-19 pandemic the educational process has been transferred to distance learning and disadvantages of it have been revealed. The negative aspects of distance learning need to be analyzed and strategies of their prevention need to be developed. An anonymous survey was conducted among students in order to know their opinion about a transfer to distant learning. Online Google Forms technology was used with this purpose. According to the obtained data, the majority of students $(58,2 \%)$ indicated a decrease in the level of knowledge acquired remotely during the quarantine. The importance of contact with teachers and receiving tasks from them during quarantine was noted by 79,6\% of respondents. Only small part of students (12,2\%) assessed distance learning positively. Most of them (75,5\%) cannot imagine isolation without using the means of communication, but in case of inability to use them, respondents $(43,8 \%)$ answered that they would 
read books. This raises an extremely important question about the dependence of the learning process on electricity. Over the half of the students admitted that the state of health (65,3\%) and mood (57,1\%) had become worse. About half of students spent their leisure time playing computer games (42,5\%), had communicated with family and friends more often (44,9\%) and felt homesick (45,9\%). These signs are the components of distress that indirectly affect the ability to learn. It is crucially important to provide the maximum audio-visual contact between the teacher and the student during distance learning. The system of psychological consulting of students is extremely needed. Classroom activity with necessary antiepidemic measures should be provided for medical students. The duration and format of online lectures, practical and laboratory classes should be changed.

Keywords: medical students, distant learning, quarantine, COVID-19 pandemic.

\section{Introduction and the current state of the research problem}

Over the past decade, the importance of online resources in education has been growing rapidly, but nowadays challenges have conditioned the lack of alternative to distance learning, in particular during the 2020 quarantine because of the COVID-19 pandemic. Distance learning has both disadvantages and advantages, which, in turn, require analysis to ensure that an appropriate quality of education is maintained.

The studies of the students' assessment of online and offline learning, which had been carried out before the implementation of quarantine measures, had been showed the dependence of the choice of learning form on expected educational achievements (Paechter, 2010). The advantages of distance learning include a certain independence from the place and time of the lesson and the simplification of the procedure for the forming of learning environment. At the same time, its disadvantages are various technical obstacles: the heterogeneity of the equipment used by the participants, the difficulty of synchronizing its operation for all participants, and the organization of feedback between students and teachers. A certain challenge is also the different level of user experience in work with modern means of communication, the lack of the necessary skills of distance communication (Keskin, Yurdugül, 2019). Considering this, initially, the online learning was perceived by the academic society mainly as an addition to traditional classroom activities. But, taking into account the advantages and prospects of distance learning, the concept of a mixed educational procedure, in which these two models are combined, had received a support with time. The research conducted on this occasion has supported distance learning. In particular, the use of the online format in bachelor's medical education turned out to be more effective in improving the knowledge and skills of students compared to offline learning (Pei, Wu, 2019). Despite this, global trend of increased usage of Internet resources, traditional approaches, such as an attendance at lectures and practical classes, remained more attractive for most medical students until 2019 (Wynter, et al., 2019).

Because of the COVID-19 pandemic, educational institutions have switched to online learning platforms. Such a global and abrupt transition to the distance learning revealed many problems of it. A significant part of the participants in the educational process in the world felt technical limitations associated with the unsuitability of their devices for online learning, low-bandwidth of communication channels, as well as the cost of access to Internet resources (Muthuprasad, et al., 2020). In this regard, a number of studies have appeared on this issue. A survey of nonmedical students revealed their willingness to learn online during a pandemic (Muthuprasad, et al., 2020). Whereas medical students expressed their reluctance to have distance mode of learning and appealed for offline learning (Abbasi, et al., 2020). Given these contradictions, further study of the personal attitude of students to distance learning and the effectiveness of its impact on the final result of the formation and assimilation of professional knowledge and skills is relevant.

This issue is especially relevant for medical students, because traditionally mastering the profession of a doctor is based on the communication of the future specialist with experienced experts, as well as the work at the patient's bedside or in simulation centers, where the teacher's control is necessary to develop the student's practical skills.

\section{Aim}

The aim of this study is to analyze some aspects of distance learning by interviewing medical students and to formulate recommendations to minimize the negative effects of distance learning in the first years of medical education.

\section{Tasks}

1. To be informed how important contact with teachers was for students during distance learning.

2. To obtain information how medical students evaluate distance learning versus classroom learning.

3. To know students' subjective assessment of own psychological state.

4. To know students' subjective assessment of the state of own health during the period of isolation.

\section{Research methods}

The study had been held on the base of Educational and Scientific Center "Institute of biology and medicine" of Taras Shevchenko National University of Kyiv during April 2020. There were 98 foreign medical students participated in the interview, between the ages of 18 and 27. All students were from other countries and came to Ukraine only with an educational purpose. The average age of the respondents was 21 years. Male were $63,3 \%$ out of all respondents. Students were asked to answer 21 questions in English. All questions were divided into two blocks. The first block included 12 questions about a subjective assessment of the distance learning and its effectiveness by respondents. The second block included 9 questions and was aimed at students' subjective assessment of their physical and psychological state during quarantine. The survey was conducted anonymously using online Google Forms technology. Students were informed about the purpose of the study and provided their voluntary consent to participate in it.

The obtained data have been expressed as a percent age of the total number of study respondents. 


\section{Research results}

The questions of the first block and the percentage distribution of students' answers are shown in Table 1. According to the results, the majority of students $(86,7 \%)$ have felt the difference between distance learning and classroom activities. Taking into account the answers to the second question, it can be stated that the most of students consider the distance form less effective $(78,6 \%)$, and $58,2 \%$ of them indicated a decrease in the level of knowledge obtained remotely during quarantine. Only $12,2 \%$ of the respondents noted the greater effectiveness of distance learning, and $22,4 \%$ of them that it is more convenient to study remotely and they liked this form of education.

Table 1

\section{Percentage ratio of students' responses about their attitude to distance learning and subjective assessment} of its effectiveness

\begin{tabular}{|c|c|c|c|}
\hline & Yes & No & I find it difficult to answer \\
\hline \multirow{2}{*}{$\begin{array}{l}\text { 1. Have you felt the differ- } \\
\text { ence between classroom and } \\
\text { distance learning? }\end{array}$} & $86,7 \%$ & $10,2 \%$ & $3,1 \%$ \\
\hline & More effective & Less effective & No difference \\
\hline \multirow{2}{*}{$\begin{array}{l}\text { 2. Do you consider distance } \\
\text { learning compared to class- } \\
\text { room learning: }\end{array}$} & $12,2 \%$ & $78,6 \%$ & $9,2 \%$ \\
\hline & More convenient & Less convenient & No difference \\
\hline \multirow{2}{*}{$\begin{array}{l}\text { 3. Do you consider distance } \\
\text { learning more convenient for } \\
\text { students compared to class- } \\
\text { room learning: }\end{array}$} & $22,4 \%$ & $73,5 \%$ & $4,1 \%$ \\
\hline & Yes & No & No difference \\
\hline \multirow{2}{*}{$\begin{array}{l}\text { 4. Was it important for you } \\
\text { to receive tasks from teach- } \\
\text { ers? Did it help you to organ- } \\
\text { ize yourself? }\end{array}$} & $62,2 \%$ & $26,7 \%$ & $10,2 \%$ \\
\hline & Yes & No & I find it difficult to answer \\
\hline \multirow{2}{*}{$\begin{array}{l}\text { 5. Would you like to always } \\
\text { have distance learning? }\end{array}$} & $13,3 \%$ & $71,4 \%$ & $15,3 \%$ \\
\hline & Yes & No & I find it difficult to answer \\
\hline \multirow{2}{*}{$\begin{array}{l}\text { 6. Has the period of distance } \\
\text { learning changed your un- } \\
\text { derstanding of the im- } \\
\text { portance and role of teachers } \\
\text { in the educational process? }\end{array}$} & $65,3 \%$ & $23,5 \%$ & $11,2 \%$ \\
\hline & Yes & No & I find it difficult to answer \\
\hline \multirow{2}{*}{$\begin{array}{l}\text { 7. Would you like to have an } \\
\text { online video conference with } \\
\text { a teacher in a future? }\end{array}$} & $55,1 \%$ & $30,6 \%$ & $14,3 \%$ \\
\hline & improved & worsened & Has not changed \\
\hline \multirow{2}{*}{$\begin{array}{l}\text { 8. Do you feel that level of } \\
\text { your knowledge in compare } \\
\text { with classroom study: }\end{array}$} & $19,4 \%$ & $58,2 \%$ & $22,4 \%$ \\
\hline & Yes & No & I find it difficult to answer \\
\hline \multirow{2}{*}{$\begin{array}{l}\text { 9. Would you continue to } \\
\text { study on your own during } \\
\text { quarantine if the teachers did } \\
\text { not control you? }\end{array}$} & $48 \%$ & $25,5 \%$ & $26,5 \%$ \\
\hline & Yes & No & No difference \\
\hline \multirow{2}{*}{$\begin{array}{l}\text { 10. Was contact with teach- } \\
\text { ers important for you during } \\
\text { quarantine? }\end{array}$} & $79,6 \%$ & $13,3 \%$ & $7,1 \%$ \\
\hline & Yes & No & \\
\hline \multirow{2}{*}{$\begin{array}{l}\text { 11. Can you imagine the iso- } \\
\text { lation without using modern } \\
\text { communication technolo- } \\
\text { gies? }\end{array}$} & $24,5 \%$ & $75,5 \%$ & \\
\hline & Reading books & Other activity & \\
\hline $\begin{array}{l}\text { 12. How would you spend } \\
\text { time if all modern means of } \\
\text { communication were ab- } \\
\text { sent? }\end{array}$ & $43,8 \%$ & $56,2 \%$ & \\
\hline
\end{tabular}


The positive assessment of distance learning could be explained by the use of the possibility to stay at home in comfortable conditions and do not waste time on the way to the university building, as well as to relatively voluntary choose the time for completing tasks. Despite this, only $13,3 \%$ of students would like to continue their distance learning. Receiving tasks from teachers helped $62,2 \%$ of respondents to organize themselves, and $65,3 \%$ of them noted the important role of a teacher in the educational process. Without teacher supervision $48 \%$ of students would have continued to study. About half of the students $(55,1 \%)$ would like to have video conferences with teachers. The importance of contact with teachers and receiving tasks from them was noted by $79,6 \%$ of students. Despite that, only $13,3 \%$ of respondents would like to continue the distance learning. Taking this into account, it can be stated that the role of the teacher in the distance educational model is changing from classical teaching to tutoring. In this model, the teacher basically indicates the direction of the educational process and controls it. If this component is completely excluded, the lack of systematic communication with the teacher can lead to a decrease in motivation to learn.

More than two thirds of the respondents $(75,5 \%)$ cannot imagine quarantine isolation without the use of modern means of communication. At the same time, in arbitrary answer to the question: "How would you spend time if all modern means of communication were absent in quarantine?" $43,8 \%$ of the respondents answered that they would read books. This raises an extremely important question about the dependence of the learning process on electricity and all resources associated with it. If imagine that during isolation, due to certain circumstances, current sources turn off or become inaccessible, the learning process will come to a halt. Considering this, no matter how convenient and modern all online technologies may seem, the global trend of their widespread introduction nevertheless reveals weaknesses. The use of books as paper carriers of knowledge remains relevant and withstands competition under the pressure of modern electronic technologies.

The distribution of answers to the second block questions regarding own physical and psychological state, as well as leisure time during quarantine is shown in the Table 2 .

Table 2

Percentage ratio of students' responses about their physical and psychological state during quarantine

\begin{tabular}{|c|c|c|c|}
\hline & More strong & Worsened & Not changed \\
\hline \multirow{2}{*}{$\begin{array}{l}\text { 1. During isolation, your re- } \\
\text { lationship with friends be- } \\
\text { came: }\end{array}$} & $45,9 \%$ & $19,4 \%$ & $34,7 \%$ \\
\hline & Yes & No & $\begin{array}{l}\text { No difference compare with } \\
\text { normal life }\end{array}$ \\
\hline \multirow{2}{*}{$\begin{array}{l}\text { 2. During quarantine, did } \\
\text { you become annoyed more } \\
\text { often when interacting with } \\
\text { people? }\end{array}$} & $48 \%$ & $26,5 \%$ & $25,5 \%$ \\
\hline & More often & Less often & $\begin{array}{l}\text { No difference compare with } \\
\text { normal life }\end{array}$ \\
\hline \multirow{2}{*}{$\begin{array}{l}\text { 3. How often per day did you } \\
\text { communicate with your rela- } \\
\text { tives during quarantine com- } \\
\text { paring with normal life? }\end{array}$} & $44,9 \%$ & $28,6 \%$ & $26,5 \%$ \\
\hline & Very strong & Moderately & Did not feel \\
\hline \multirow{2}{*}{$\begin{array}{l}\text { 4. How much did you feel } \\
\text { homesick? }\end{array}$} & $45,9 \%$ & $38,8 \%$ & $15,3 \%$ \\
\hline & More time & Less time & No change \\
\hline \multirow{2}{*}{$\begin{array}{l}\text { 5. How much time did you } \\
\text { play computer games during } \\
\text { isolation compared to nor- } \\
\text { mal life? }\end{array}$} & $42,9 \%$ & $26,5 \%$ & $30,6 \%$ \\
\hline & More often & Less often & No difference \\
\hline \multirow{2}{*}{$\begin{array}{l}\text { 6. Did you have a bad mood } \\
\text { during the isolation period } \\
\text { more often compared with } \\
\text { other days? }\end{array}$} & $57,1 \%$ & $25,5 \%$ & $17,3 \%$ \\
\hline & Yes & No & No difference \\
\hline \multirow{2}{*}{$\begin{array}{l}\text { 7. Did you feel worse during } \\
\text { isolation? }\end{array}$} & $65,3 \%$ & $23,5 \%$ & $11,2 \%$ \\
\hline & Yes & No & I had no on-line talk \\
\hline \multirow{2}{*}{$\begin{array}{l}\text { 8. Have your mood being } \\
\text { improved after having online } \\
\text { talk with teachers? }\end{array}$} & $40,8 \%$ & $29,6 \%$ & $29,6 \%$ \\
\hline & $\begin{array}{l}\text { positively, I was able to have } \\
\text { a rest from hectic lifestyle }\end{array}$ & $\begin{array}{c}\text { negatively, I can't stay at } \\
\text { home }\end{array}$ & I find it difficult to answer \\
\hline $\begin{array}{l}\text { 9. What do you think about } \\
\text { quarantine? }\end{array}$ & $45,9 \%$ & $23,5 \%$ & $30,6 \%$ \\
\hline
\end{tabular}


During the period of forced isolation, the attitude of the respondents towards others, close people, teachers, and the opportunity to communicate with them changed especially.

Among surveyed, 44,9\% noted that they had communicated with family and friends more often, and $45,9 \%$ felt homesick. The time of quarantine isolation made the relationship with friends stronger for $45,9 \%$ of students, while in $19,4 \%$ the relations with relatives become worse. It is probably due to the growth of irritation, which was noted by $48 \%$ of the respondents. More than half of the students noted that their health $(65,3 \%)$ and $\operatorname{mood}(57,1 \%)$ had become worse, $42,5 \%$ of students spent more time playing computer games. It is worth noting that communication with teachers turned out to be a factor of improving of their well-being under conditions of distance learning in $40,8 \%$ of respondents.

\section{Discussion}

Active learning can be defined as any kind of teaching that involves students in the learning process (Prince, 2004). It is aimed at comprehensive activation of educational and cognitive activities through the wide, complex use of didactic, organizational, and managerial methods. If students acquire knowledge actively through their participation, the learning is the most effective. A necessity to synthesize, evaluate and create opens opportunities for higher order thinking and memorizing information (Birks, et al., 2011). Methods of active teaching include interaction with educational materials in authentic and simulated environments, group and project work based on specific situations and problems, cooperation with other students (Zepke, et al., 2010). Active learning encourages participation, interaction and involvement of participants, but also requires effective pedagogical practice (Vaughan, et al., 2013). All mentioned statements could be achieved relatively easily in a classroom. Australian authors in their literature review conclude that the effectiveness of the pedagogy of active learning in higher education is well supported by evidences (Kumar, et al., 2017).

As it is seen from our research, subjectively, students felt the lack of the active component in the distance work: $78,6 \%$ noted that distance learning is less effective comparing with classroom activities, 62,2\% needed constant monitoring of teacher for the work organization, $71,4 \%$ would not like to study remotely on a permanent base, $65,3 \%$ understood the importance of the teacher in the learning process.

Distance learning complicates the implementation of an individual approach to students. As a result, students with poor self-organization are deprived of the chance to acquire high-level knowledge and competencies. Assimilating new professional information off one's own bat, without the guidance of a person who has already had the experience in that field, without communication, making mistakes, discussing them with the teacher, causes additional difficulties in the learning process for students.

The concept of active learning has a physiological base. In a research of learning mechanisms in mice, it had been shown that the study of a new motor skill (running on a wheel with unevenly spaced bars) had been changed the structure of the white matter of animals' brain. It is known that myelin-forming oligodendrocytes (OL) are constantly formed in the brain of a healthy adult and organize the white matter of the brain. This research suggested that new OLs (late-born OLs) may contribute to the familiarization of motor skills. McKenzie et al. had blocked the production of new late-born OLs in adult animals, without affecting existing OL or myelin by genetical manipulations with the regulatory factor of myelin transcription. That change had prevented the mice from mastering the complex wheel. Thereby, the production of new OL and myelin is important for the formation of motor skills (McKenzie, et al., 2014).

This mechanism of new motor skills developing attracts attention. Educational programs of medical and humanitarian specialties require the acquisition of competencies that are often impossible to obtain remotely. Among the general competencies it could be: the ability to apply knowledge in practical situations, the ability to adapt and act in a new situation, skills to work in a team, interpersonal interactions; professional competencies: the skill of interviewing the patient, the ability to provide emergency medical care, ability to carry out medical and evacuation procedures, skills to perform medical manipulations. It is not possible to master such kinds of competence without active involvement, repeated training and reproduction of the described actions.

One of the factors that also determine mental activity is the level of myelination. Central nervous system of a human being contains a very high percentage $(\sim 50 \%)$ of white matter which is supported by the activity of oligodendrocytes (Fields, 2008). White matter abnormalities are associated with mental disorders, including schizophrenia and autism (Burghardt, et al., 2012). These states are genetically related to the impairment in intelligence. Penke et al. had found that genes involved in myelination of the central nervous system were associated with cognitive functions and had established the molecular-genetic base of the connection between the structure of white matter pathways and intelligence (Penke, et al., 2012). Thereby, it could be assumed that distance learning with its lack of practical component, does not provide a sufficient level of myelination, does not contribute to the acquisition of new skills and the development of intellectual abilities. The active participation of students in the educational process becomes minimal and limited by work exclusively with computers or textbooks.

The connection of cognitive processes with sensory information perceived by the brain is also important for the learning process. For instance, Butler and James conducted an investigation of the interaction of motor and sensory systems during training. The authors used brain imaging technologies to elucidate the difference between passive and active learning. During the experiment, participants formed visual-auditory-motor associations between new objects and the sounds which they produce. In one case, the respondents were actively involved in the action with objects (active learning), in other case, they received information by observing an experimenter's performing actions (passive learning). Active learning was faster and led to more accurate recognition of audiovisual associations than passive learning. Functional analyses had showed that in 
motor, somatosensory and cerebellar regions of brain greater neuronal activation was during both the perception and recognition of actively learned associations. In addition, functional connectivity between visual-related and motor-related processing regions had been enhanced during the presentation of actively learned audiovisual associations (Butler, James, 2013). As distance learning belongs to type of passive learning that eliminates a practical component, it significantly limits cognitive functions of human brain. For example, watching a video where a teacher explains the structure of a skull is not the same as a student holding that skull in his/her hands. It may seem subjectively that there is no difference, but for our brain the difference is very significant. As it was mentioned above, more numbers of brain areas are involved in active learning, new connections are formed between these areas and this ensures the effectiveness of the process. Effective learning is not only the ability to reproduce the material after its study, but the ability to operate on the acquired knowledge and reproduce it over a long period of time. Because passive learning activates fewer areas of the cerebral cortex; it can be argued that over time, such connections are easier to lose and, subjectively, to forget the studied material.

In addition, distance learning eliminates the emotional component or minimizes it. Emotions are essential for memorizing of new information (Chai, et al., 2017; Marchand, Gutierrez, 2012). Implementation of online lecture as a non-alternative method under the quarantine conditions saves time and effort. But the impact of the lecturer on the audience, the perception of a living voice and a living person, is lost, what is important for the brain, since evolutionarily communication was formed between living people. It is known that the psychophysiological component, in particular the feeling of positive or negative emotions, is important for the learning process. Emotional speech is remembered better and longer. This has always been the basis of the art of influencing the audience to ensure easy assimilation of the information that the lecturer aims to convey.

Distance learning also deprives medical students of the opportunity to learn how to work in a team. After graduation, future doctors are awaited by a team whose work efficiency depends on the team spirit of its members.

The second block of our study is devoted to students' subjective assessment of their psychological state. During isolation, $48 \%$ of students noted an increase in irritation while communicating with other people, $57,1 \%$ observed anxiety, $65,3 \%$ complained of worse health compared to normal conditions, $50 \%$ felt a longing for home, $43 \%$ played computer games more often than usually. The described states are components of distress, that indirectly affect the ability to learn.

It is known that uncontrolled distress affects the hippocampus at its different levels. Behavioral research had found that distress tends to impair the complete of tasks that require memorization. In particular, it had been found that distress altered the synaptic plasticity and properties of hippocampal neurons, their morphology, inhibited their proliferation and reduced the volume of the hippocampus as a whole (Kim, et al., 2015). The data of our research showed that more than half of the students experienced distress to a greater or lesser extent, which could affect the effectiveness of their studies. This is agreed with the results of another study that also found an impairment of well-being and working capacity of students in quarantine (Meo, et al., 2020). On the other hand, 45,9\% of students noted that the opportunity to take a break from the hectic pace of life was one of the positive aspects of the isolation.

It is worth noting the negative aspects of the impact of distance learning on health. It is known that the time spent in front of a computer or laptop screen should be limited. It is necessary to be distracted every 15-20 minutes and to take a break and do physical exercises with prolonged sitting. If we consider that the duration of a lesson at a university is from 1,5 to 3 hours, and during the day there are several lessons for both students and teachers, the total time spent in front of the monitor increases significantly. Such hypodynamia is a risk factor provoking disorders in the cardiovascular system. An additional load is created on the organs of vision.

In addition, a distance lecture should not have the same duration as a lecture held in the lecture hall. First of all, the time spent in front of monitor screen increases. Furthermore, if a student can be a passive participant and perceive such a lecture as watching a video, the tension for the teacher is much higher. In the lecture hall, during the presentation of information, the teacher has the opportunity to gesture, walk and in a such way compensate for the phenomena of activation of the sympathoadrenal system. During an online lecture, this task becomes more difficult. A necessity to make a monologue emotional is faced a limitation of an ability to perform physical movements. The factor of additional stress on the cardiovascular system appears again. It is known that adrenaline is released during the activation of sympathoadrenal system and destroyed by the enzyme monoamine oxidase, which is synthesized in skeletal muscles during their active contraction. In case of this enzyme lack, that takes place under conditions of hypodynamia, the effect of adrenaline on the cardiac muscle becomes toxic. It follows from the above that during distance learning, the time of daily physical activity should be increased.

To sum up, it can be stated that for most of the respondents quarantine isolation turned out to be a serious trial. Well-being, social relations and learning were suddenly destroyed. An important result of our research should be considered the deterioration of the effectiveness of the educational process noted by the majority of medical students.

\section{Conclusions}

The global pandemic of 2020 due to COVID-19 forced to disrupt the traditional course of life and in particular the process of learning in medical education. The students had found themselves in a state of stress, which affected both the effectiveness of their studies and their wellbeing. However, in order to counteract the disease and not lose the proper quality of life and education, it is necessary to develop certain provisions that would allow to avoid the negative effects of the pandemic in the future. In developing these attitudes, it is necessary to take into consideration the views of scientists as well as teachers and students as 
participants in the learning process. Regarding the recommendations for medical students, the following should be taken into account:

1. In developing medical educational platforms that contain educational materials for interactive classes and self-dependent work, it is necessary to provide maximum audio-visual communication between teacher and student, as well as students with each other.

2. Classroom activity should be provided for medical students with the necessary anti-epidemiological measures.

\section{References}

1. Abbasi, S., Ayoob, T., Malik, A., Memon, S. I. (2020). Perceptions of students regarding E-learning during Covid-19 at a private medical college. Pak J Med Sci., 36 (COVID19-S4), 57-S61. DOI: https://doi.org/10.12669/pjms.36.COVID19S4.2766 [in English].

2. Birks, M., Cant, R., Al-Motlaq, M., Jones, J. (2011). "I don't want to become a scientist": undergraduate nursing students' perceived value of course content. Australian Journal of Advanced Nursing, 28 (4), 20-27 [in English].

3. Burghardt, N. S., Park, E. H., Hen, R., Fenton, A. A. (2012). Adult-born hippocampal neurons promote cognitive flexibility in mice. Hippocampus, 22 (9), 1795-1808. DOI: https://doi.org/10.1002/hipo.22013 [in English].

4. Butler, A. J., \& James, K. H. (2013)._Active learning of novel sound-producing objects: motor reactivation and enhancement of visuo-motor connectivity. Cognitive Neuroscience, 25 (2), 203-218. DOI: https://doi.org/10.1162/jocn_a_00284 [in English].

5. Chai M. Tyng, Hafeez U. Amin, Mohamad N. M. Saad, Aamir S. Malik (2017). The Influences of Emotion on Learning and Memory. Frontiers in Psychology, 8 (1454). DOI: https://doi.org/10.3389/fpsyg.2017.01454 [in English].

6. Fields, R. D. (2008). White matter in learning, cognition and psychiatric disorders. Trends Neurosci., 31 (7), 361-370. DOI: https://doi.org/10.1016/j.tins.2008.04.001 [in English].

7. Keskin, S., \& Yurdugül, H. (2019). Factors Affecting Students' Preferences for Online and Blended Learning: Motivational Vs. Cognitive. European Journal of Open, Distance and E-Learning, 22 (2), 72-86. DOI: https://doi.org/10.2478/eurodl-2019-0011 [in English].

8. Kim, E. J., Pellman, B., Kim, J. J. (2015). Stress effects on the hippocampus: a critical review. Learning \& Memory, $\quad 22$ (9), 411-416. DOI: https://doi.org/10.1101/lm.037291.114_[in English].

9. Kumar, S., McLean, L., Nash, L., Trigwell, K. (2017). Incorporating active learning in psychiatry education. Australas Psychiatry, 25 (3), 304-309. DOI: https://doi.org/10.1177/1039856217689912 [in English]

10. Marchand, G. C., \& Gutierrez, A. R. (2012). The role of emotion in the learning process: Comparisons between online and face-to-face learning settings. The Internet and Higher Education, 15 (3), 150-160 [in English].

11. McKenzie, I. A., Ohayon, D., Li, H., Paes de Faria, J., Emery, B., Tohyama, K., et al. (2014). Motor skill
3. The system of psychological online assistance for students should function in educational institutions.

4. Distance learning cannot be conducted according to the same schedule and duration of classes provided for offline lessons. It is necessary to develop standards that would take into account all the negative factors of the impact of prolonged stay in front of the computer on health. With this in mind, the format and duration of lectures and practical classes should be changed.

learning requires active central myelination. Science, 346 (6207), 318-322. DOI: https://doi.org/10.1126/science. 1254960 [in English].

12. Meo, S. A., Abukhalaf, A. A., Alomar, A. A., Sattar, K., Klonoff, D. C. (2020). COVID-19 Pandemic: Impact of Quarantine on Medical Students' Mental Wellbeing and Learning Behaviors. Pak J Med Sci., 36(COVID19S4), 43-48.

DOI: https://doi.org/10.12669/pjms.36.COVID19S4.2809 [in English].

13. Muthuprasad, T., Aiswarya, S., Aditya, K. S., Girish, K. Jha. (2020). Students' Perception and Preference for Online Education in India During COVID-19 Pandemic. Available at SSRN. DOI: https://doi.org/10.2139/ssrn.3596056 [in English]

14. Paechter, M. (2010). Online or face-to-face? Students' experiences and preferences in e-learning. The Internet and Higher Education, 13 (4), 292-297. DOI: https://doi.org/10.1016/J.IHEDUC.2010.09.004_[in English].

15. Pei, L., \& Wu, H. (2019). Does online learning work better than offline learning in undergraduate medical education? A systematic review and meta-analysis. Medical Education Online, 24 (1), 1666538. DOI: https://doi.org/10.1080/10872981.2019.1666538 [in English].

16. Penke, L., Maniega, S. M., Bastin, M. E., Valdes Hernandez M. C., Murray, C., Royle, N. A., et al. (2012). Brain white matter tract integrity as a neural foundation for general intelligence. Mol Psychiatry., 17 (10), 1026-1030. DOI: https://doi.org/10.1038/mp.2012.66 [in English].

17. Prince, M. (2004). Does active learning work? A review of the research. J. Eng. Educ., 93 (3), 223-231. DOI: https://doi.org/10.1002/j.2168-9830.2004.tb00809.x [in English].

18. Vaughan, N. D., Garrison, D. R., ClevelandInnes, M. (2013). Teaching in Blended Learning Environments: Creating and Sustaining Communities of Inquiry. Edmonton, AB: AU Press [in English].

19. Wynter, L., Burgess, A., Kalman, E., Heron, J. E., Bleasel, J. (2019). Medical students: what educational resources are they using? BMC Med Educ., 19 (1), 36. DOI: https://doi.org/10.1186/s12909-019-1462-9 [in English].

20. Zepke, N., Lea, L., Butler, P. (2010). Student engagement: what is it and what influences it. Teaching and Learning Research Initiative. Crown; http://www.tlri.org.nz/sites/default/files/projects/9261-Introduction.pdf [in English]. 
Марія Бондаренко,

кандидат біологічних наук, асистент кафедри анатомії та патологічної фізіології,

ННЦ «Інститут біологї та медицини»

Киїського національного університету імені Тараса Шевченка, проспект Академіка Глушкова, 2, Київ, Украӥна,

Валентина Куровська, кандидат медичних наук, асистент кафедри фундаментальної медицини, ННЦ «Інститут біології та медиични» Київського національного університету імені Тараса Шевченка, проспект Академіка Глушкова, 2, Київ, Україна,

Артем Охрей,

кандидат біологічних наук, асистент кафедри анатомії та патологічної фізіології,

ННЦ «Інститут біології та медиични» Киівського національного університету імені Тараса Шевченка, проспект Академіка Глушкова, 2, Київ, Україна,

Ольга Подпалова, асистент кафедри фундаментальноїмедицини,

ННЦ «Інститут біології та медицини» Київського національного університету імені Тараса Шевченка, проспект Академіка Глушкова, 2, Київ, Україна,

Свдокія Решетнік,

кандидат біологічних наук, асистент кафедри анатомії та патологічної фізіології,

ННЦ «Інститут біології та медицини» Киівського національного університету імені Тараса Шевченка, проспект Академіка Глушкова, 2, Киї, Украӥна

\section{ПРОБЛЕМИ ДИСТАНЦЙНОГО НАВЧАННЯ \\ СТУДЕНТІВ-МЕДИКІВ ПІД ЧАС ПАНДЕМІї COVID-19}

Традиційно практична складова займає значну частину в медичній освіті. Однак, під час карантину, зумовленого пандемією COVID-19, навчальний процес перейшов на дистанційний формат. Це дозволило чітко визначити його недоліки. Проаналізувати недоліки дистанційного навчання з метою формулювання висновків щодо їх усунення. Анонімне опитування було проведено серед студентів для визначення їхньої думки щодо переходу на дистанційну форму навчання. Згідно отриманих даних, більшість студентів $(58,2 \%)$ відмітили зниження рівня знань, отриманих дистанційно впродовж карантину. Важливість контакту з викладачами та отримання від них завдань впродовж карантину відмітили 79,6\% респондентів. Тільки незначна частина студентів (12,2\%) оцінили дистанційне навчання позитивно. Більшість із них $(75,5 \%)$ не можуть уявити ізоляцію без використання сучасних засобів комунікації, однак, у випадку неможливості їх використання, 43,8\% опитуваних відмітили, що вони читали б книжки. Це піднімає вкрай важливе питання про залежність навчального процесу від електричної енергії. Більш ніж половина студентів, відмітили, що стан їхнього здоров'я $(65,3 \%)$ та настрій $(57,1 \%)$ погіршились. Приблизно половина студентів проводили свій вільний час, граючи в комп'ютерні ігри (42,5\%) та відчували тугу за рідними $(45,9 \%)$. Ці ознаки є компонентами дистресу, що опосередковано впливає на здатність до навчання. Під час дистанційного навчання вкрай важливим є забезпечення максимального аудіо- та відео зв'язку між студентами та викладачами. Необхідне функціонування системи психологічної допомоги студентам. Для студентів медиків повинно бути передбачене аудиторне навчання, з дотриманням усіх протиепідемічних заходів. Тривалість та формат online лекцій, практичних та лабораторних занять повинені відрізнятися від аудиторних.

Ключові слова: студенти-медики, дистанційне навчання, карантин, пандемія COVID-19.

Подано до редакиії 12.02.2021 